\title{
Corruption, Rule of Law, and Economic Efficiency: Virginia vs. Chicago Public Choice Theories
}

\section{Korupce, právní stát a ekonomická efektivnost zpohledu Virginské a Chicagské větve teorie veřejné volby}

\section{LADISLAVA GROCHOVÁ, TOMÁŠ OTÁHAL}

\begin{abstract}
Can corruption improve economic efficiency? Classical political economists argue that corruption undermines the rule of law (Smith, 2001, chap. 5). The modern Public Choice proponents argue that corruption and lobbying might influence the efficiency of the rule of law. While Chicago Public Choice scholars model how legal lobbying, which is corruption in V irginia Public Choice perspective, improves efficiency of the rule of law and thus the overall economic efficiency, the Virginia Public Choice models explain how corruption reduces efficiency of the rule of law and thus the overall economic efficiency. In this short paper, we present a brief survey distinguishing between arguments of the Chicago Public Choice and Virginia Public Choice schools on how corruption influences economic efficiency. We argue that the Virginia Public Choice explanation is more realistic because it includes the influence of bureaucratic rent-seeking.
\end{abstract}

\section{Keywords}

bureaucracy, corruption, economic efficiency, Chicago Public Choice, lobbying, Virginia Public Choice, rent-seeking, rule of law

\section{JEL Codes}

D74, K42, P3

\section{Abstrakt}

Může korupce zlepšit ekonomickou efektivnost? Klasičtí političtí ekonomové tvrdí, že korupce narušuje fungování právního státu (Smith, 2001, kapitola 5). Moderní teoretici veřejné volby argumentují, že korupce a lobbing ovlivňují efektivitu fungování právního státu. Zatímco chicagská větev veřejné volby modeluje, jak legální lobbing zájmových skupin zvyšuje efektivitu právního státu a tím i celkovou ekonomickou efektivnost, virginská větev teorie veřejné volby vysvětluje, jak korupce a lobbing snižují efektivní fungování právního státu a tím i celkovou ekonomickou efektivnost. V tomto př́spěvku prezentujeme stručný přehled argumentů v diskusi mezi chicagskou větví teorie veřejné volby a virginskou větví teorie veřejné volby vysvětlující, jak korupce a lobbing zájmových skupin ovlivňuje ekonomickou efektivnost. Tvrdíme, že virginská větev veřejné volby nabízí realističtější pohled, protože vysvětluje vliv byrokratického dobývání renty. 


\section{Klíčová slova}

byrokracie, dobývání renty, ekonomická efektivnost, chicagská veřejná volba, korupce, lobbování, právní stát, virginská veřejná volba

\section{Introduction}

Can corruption improve economic efficiency? The economic theory of Adam Smith (17231790) assumes that the state is a necessary part of market organization. Economic theorists thus deal with the state as a precondition for a successful economic organization. However, Adam Smith in Wealth of Nations, criticizes Mercantilism as the doctrine of the state interventionism (Smith, 2001, chap. 5) to suggest an alternative way of social organization where the state enforces rules protecting private property, and allows the emergence of private enterprises - the rule of law (Smith, 2001, chap. 5).

Classical political economists were aware of the danger that corruption poses for the rule of law, but they did not develop any appropriate analytical apparatus for dealing with this problem. ${ }^{1}$ They suggested that the rule of law can prevent discretionary public policies, which can create barriers to entry restricting economic development. This was the reason why it was necessary to provide such system of governance that avoids creation of governmental privileges in favour of particular classes. Almost one hundred years later, Public Choice theoreticians filled this gap and developed more comprehensive analytical apparatus providing a more rigorous explanation of the corruption problem and its effects on the efficiency of the rule of law. As James M. Buchanan states: "If I am allowed to use Thomas Kuhn's overly used word here, we can, I think, say that a new paradigm has been substituted for an old one. Or, to go somewhat further back, and to use Nietche's metaphor, we now look at some aspects of our world, and specifically our world of politics, through a different window." (Buchanan and Tollison, 1999, p. 11)²

Public Choice theoretical analysis in its attempt to explain effects of corruption on efficiency of the rule of law, however, does not reach an agreement about how corruption effects overall economic efficiency. While Chicago Public Choice scholars argue that lobbying (for Virginia Public Choice even lobbying might be considered as corruption) can lead to efficient regulation provided by the state and thus improve economic efficiency (Posner, 1974, Becker 1983), Virginia Public Choice proponents argue that the state behaves rather as a benevolent despot than homo economicus ${ }^{3}$, so that the provision of the rule of law by the state cannot be efficient unless the benevolent despot is constrained by the constitution (Buchanan and Tullock 1965, Brennan and Buchanan, 1977) therefore corruption reduces overall economic efficiency (Tullock, 1996). While Chicago Public Choice understands lobbying as a legal activity, which can improve the economic efficiency, Virginia Public Choice understands legal lobbying as corruption, which reduces economic

1 In this paper l assume that corruption is a problem of the governmental organization rather than the market system (Banfield, 1975, Otáhal ,2007).

2 For the survey of Public Choice literature with some implications for public policy, see Schwarz (2001).

3 We define the benevolent despot as an agent who maximizes political power. Homo economicus is defined as an agent who maximizes utility in the market. 
efficiency. Given the assumption of a benevolent despot, in Virginia Public Choice framework corruption or legal lobbying reduces economic efficiency through rent-seeking (Tullock, 1967, Krueger, 1974).

In this paper we survey the Public Choice contributions to the economic theory of corruption, identify theoretical discourse among the Chicago Public Choice and Virginia Public Choice proponents and synthesize the more realistic Virginia Public Choice theory with a theory of corruption. We extend Lambsdorff (2002) who presents an argument based on uncertain effects of corruption on economic efficiency when rent provided by a politician-bureaucrat ${ }^{4}$ is endogenous. Our explanation in essence represents the extension of seminal Public Choice theoretical contributions based on Brennan and Buchanan (1977, 1981) theory of benevolent despot, rent-seeking theory (Tullock, 1967, Krueger, 1974) and Downs (1965) and Niskanen (1968) theory of bureaucracy. Our theoretical framework implies that in the world where bureaucracy provides public goods, including the rule of law, politicians must cover the inefficiencies of bureaucracy. This provides the source of the endogenous rent-seeking.

In the next section, we explain that the assumption of a politician-bureaucrat behaving as a benevolent despot means the behavior of homo economicus in an institutional framework, which does not transform private interest into public interest as efficiently as free markets (Buchanan and Brennan, 1977, 1981). We define corruption analogically. Since corruption is in essence a particular type of exchange, the task of the theoretical analysis of corruption is to explain how such particular exchange reduces economic efficiency within the particular institutional framework.

In the second section we summarize the Chicago Public Choice theoretical arguments explaining effects of legal lobbying on economic efficiency. According to this theoretical framework, competing pressure groups might "bribe" politicians to induce them to create legislation that improves economic efficiency (Posner, 1974, Becker, 1983). This argument, however, assumes that politicians behave rather as homo economicus. Within the theoretical framework of Virginia Public Choice this assumption in essence means that benevolent despots are constrained by constitutions efficiently.

The third section explains Virginia Public Choice theoretical arguments. It argues that it is more realistic to assume that politicians behave as benevolent despots rather than homo economicus, because in the world where bureaucracy (Downs, 1968, Niskanen, 1968) provides public goods politicians and bureaucrats are not always constrained by constitutions efficiently. Moreover, it needs to be emphasized that bureaucrats also provide the rule of law inefficiently (Tullock, 1967, Krueger, 1974).

In the fourth section we explain a rent-seeking model with corruption when rent is endogenous (Lambsdorff, 2002). We argue that economic efficiency might be reduced significantly when there is a low number of pressure groups, bureaucrats included, competing for rents through lobbying and corruption. Endogenous bureaucratic rent-seeking can

4 Politician-bureaucrat represents the government, which consists of both politicians and bureaucrats. 
serve as a principal explanation of negative effects of lobbying and corruption on the overall efficiency.

In the fifth section we support our theoretical arguments empirically with selected unique anecdotic evidence of bureaucratic corruption from the early period of transition in the Czech and Slovak Republics. The source of the presented evidence is mostly the Czech and Slovak newspapers which reported on political corruption. It builds on previous studies presented by Otáhal (2006b, 2007a). Early transition of Central and Eastern Europe might be referred to as a period of creation of new legislation within old bureaucratic practices when a lot of interest groups were able to compete for the creation of legislation. For this reason, we understand this time period in Central and Eastern Europe as quasi-experimental environment allowing relatively intensive competition among interest groups.

The conclusions present a brief summary and suggestions for public policy.

\section{Public Choice Economic Analysis of Corruption}

Brennan and Buchanan (1977) inspire the theoretical analysis of corruption. They developed a Leviathan model of the budget-maximizing or revenue-maximizing politicianbureaucrat. Assuming that the budget-maximizing or revenue-maximizing politicianbureaucrat represents a monopoly in provision of public goods, they argued that while tax payers are not uniform, progressive taxation might lead to maximum revenue levied by the politician-bureaucrat. However, this only applies if it is efficiently set in constitution otherwise it creates the danger of undesired tax revenue extracted from tax payers. Later Brennan and Buchanan (1981) argued that the task of the homo economicus microeconomic assumption is to provide an as if condition for testing whether particular institutions serve to transform private interests into public interests. Thus, according to Brennan and Buchanan (1981), it is more realistic to assume that politician-bureaucrat behaves as a benevolent despot since if we assume that the politician-bureaucrat behave as homo economicus, we cannot present that political organization transforms private interests into public interests as efficiently as freely operating markets.

Per analogic, the difference between the behavior of homo economicus and corrupt behavior might be explained. Without the explanation of institutional conditions where corruption happens, the theoretical analysis of corruption would not make any sense because there would be no difference between homo economicus's behavior and corrupt behavior and thus no explanation how corruption influences overall economic efficiency (Otáhal, 2006a). This is also the reason why it is difficult to rigorously define what corruption is. Most scholars use the simplest example of bribery as an illustration of corrupt behavior (i.e. Shleifer and Vishney, 1993, Rothbard, 2001, 172). It is useful to define corruption as bribery, which is a voluntary exchange between economic agents, where a bribe is the price paid by an agent buying a particular service provided by another particular agent because this wider definition of corrupt behavior allows us to synthesize several theoretical approaches. The economic problem of corruption then arises from the fact that when we speak about corruption, we usually do not assume only two parties in the corrupted exchange, but also a third party, whose interest is harmed if the corrupt exchange takes place (Otáhal, 2007b, Colombatto, 2003). The question of theoretical analysis of corruption therefore is: What are the institutional conditions which transform private interests 
of corrupt agents so that they harm third party's interest or, alternatively, public interest or the overall efficiency?

\section{Chicago Public Choice Theory and Lobbying}

In a theory referred to as the theory of regulation, the Chicago Public Choice presents the argument that the legal lobbying improves economic efficiency. The seminal paper on the theory of regulation is credited to Stigler (1971). He argues that the purpose of governmental control of economic organizations is not the protection of the public interest, but the protection of controlled economic organizations against competition. Stigler (1971) generally argues that: "...every industry or occupation that has enough political power to utilize the state will seek to control entry. In addition, the regulatory policy will often be fashioned to limit the rate of growth of new firms." (Stigler, 1971, p. 5) ${ }^{5}$

Peltzman (1976) follows Stigler and provides the general theoretical apparatus that applies to the economic analysis of the state protection. The process is effective because political agenda is not transparent, political issues in political campaigns are mixed and displeased voters are not motivated to spend resources for gathering information to oppose the interest groups. ${ }^{6}$ In the Peltzman's (1976) model, interest groups get their wealth transfer from voters through taxation.

In compliance with Stigler (1971) and Peltzman (1976), Posner (1974) argues that the source of regulatory inefficiency is the fact, that the regulatory agencies are not profitseeking organizations. Since the regulatory agencies are bureaucratic organizations they are not interested in lowering costs. ${ }^{7}$ More importantly, the problem with regulation is that the regulatory agencies are not able to recognize the costs of the regulated industry. Inability of the regulatory agencies to overcome the information asymmetry incites the interest groups to pressure politicians to create new legislation in a nontransparent political process. Posner (1974) even suggests that the competition between interest groups can thus result in efficient regulation.

Later, Becker (1983) elaborates on Posner's suggestion about efficient regulation. Becker (1983) assumes that the outcome of political competition is the result of competition among interest groups, not the result of voters' decision-making. Becker (1983) in compliance with Peltzman (1976) explicitly argues that since the transfers from voters to interest groups through taxes create dead-weight loss, the interest groups will compete only if the outcome of the political competition brings them the rent that covers the costs of political competition and the dead-weight loss as well. Thus if dead-weight loss from taxation is too high, the interest groups will not be encouraged to enter political competition

5 Olson (1971) develops the interest group theory in which interest groups influence political decision making independently on voters' preferences. Stigler (1971) uses a similar assumption.

6 This proposition is similar to Virginia Public Choice proposition referred to as rational ignorance (Buchanan and Tullock, 1967, chap. 4).

7 Rigorous theory of revenue maximizing bureaucrat is credited to Virginia Public Choice (Downs, 1965, Niskanen, 1968). 
because the transfer will not cover losses. On the other hand, if the taxation from other interest groups covers too high dead-weight loss, the other interest groups will invest resources into changing the regulation. Thus the competition between interest groups reduces the dead-weight loss. From the perspective of the politicians' decision making, interest groups whose dead-weight loss is covered by taxation raise $b$ to incite the politicians to create efficient regulation. From Beckers' (1983) perspective corruption leads to efficient regulation and thus improves overall economic efficiency. ${ }^{8}$

\section{Virginia Public Choice Theory and Corruption}

The Chicago Public Choice theory suggests that legal lobbying might improve overall economic efficiency. From the perspective of the Public Choice analytical apparatus this conclusion, however, represents the case when the politician-bureaucrat behaves as a homo economicus rather than a benevolent despot. Nevertheless, political organization is not a market therefore the exchange behavior similarly to lobbying ought to have less than efficient results within political organization.

From the perspective of the Virginia Public Choice theory, the Chicago Public Choice conclusion is not realistic because the behavior of the politician-bureaucrats is not, in reality, efficiently constrained by constitutions. As Becker (1983) explicitly says: "Groups compete within the context of rules that translate expenditures on political pressure into political influence and access to political resources. These rules may be embodied in political constitutions and other political procedures, including perhaps 'rules' about the use of force to seize power" (Becker, 1983, p. 374). Within the assumption of an efficiently constrained politicianbureaucrat Gary Becker's conclusion that legal lobbying improves the overall efficiency is valid, but there must be no space for illegal corruption which exists in the most political systems in the world, therefore the Virginia Public Choice theory raises another question of theoretical analysis of corruption: How does corruption reduce overall efficiency?

Brennan and Buchanan $(1977,1981)$ suggest that a benevolent despot ${ }^{9}$ might impose tax on private agents undesirably. Such undesirable taxation induces bureaucracies, which maximize revenues to extract undesired taxation from politicians. ${ }^{10}$ Therefore, both, the tendency of politicians to tax private agents undesirably and the tendency of bureaucracies to extract undesired taxation from politicians, represent rent-seeking. According to the Virginia Public Choice school of thought, rent-seeking is the reason for the rule of law (Tullock, 1996) and it is also the explanation of negative effects of corruption on the overall efficiency. Let us therefore explain how corruption reduces economic efficiency within a rent-seeking model.

8 This approach is highly criticized by Olson (1996).

9 This approach was more examined by Olson (1993), McGuire and Olson (1996), North and Wallis and Weingast (2009).

10 Here, we assume that a government consisting of politicians and bureaucrats is divided between both politicians and bureaucrats. This approach is typical for Virgina Public Choice that models behavior of both politicians (political parties) and bureaucrats. Politician-bureaucrats representing politicians and bureaucrats together is a typical proposition for Chicago Public Choice. 
Figure 1: Rent-seeking

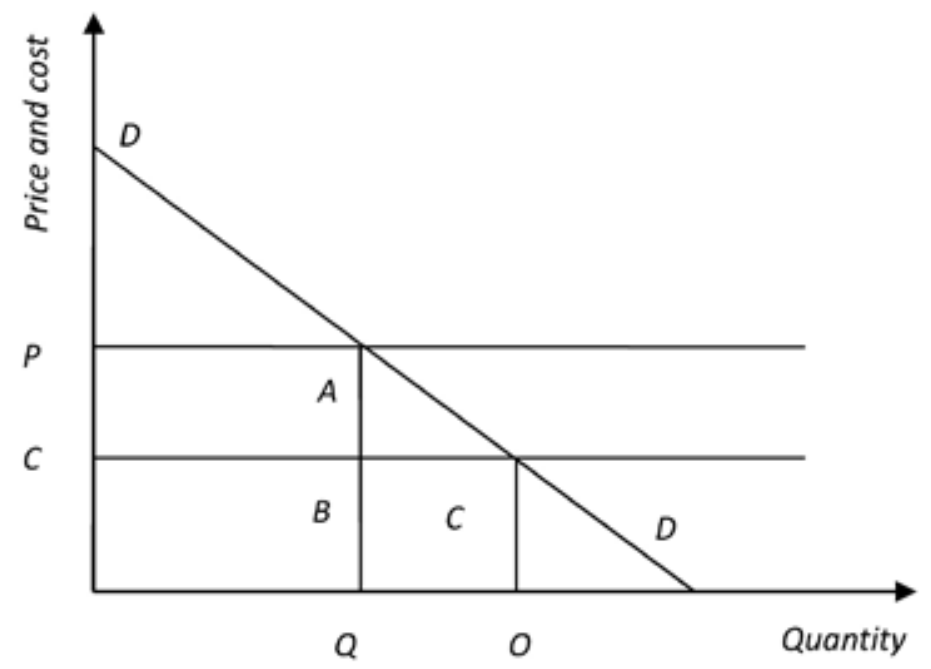

Source: Tullock (1967)

Figure 1 presents the classical rent-seeking diagram. Let us assume that in a competitive market a product for which there is a demand $D$ can be produced at cost $C$. Quantity $O$ would thus be produced at price $C$. Let us suppose, however, that it is possible for politicians to change the regulations in exchange for bribes so that they protect pressure group's production against competition. According to the theory of monopoly (Varian, 1995, chap. 23), the area of triangle $A B C$ is a death-weight loss $(D W L)$, but rent-seeking theory (Tullock, 1967, Krueger, 1974) ${ }^{11}$ maintains this is an underestimation of true costs. Since inducing the politicians to change the regulations and changing the regulation itself is costly, rectangle $P C B A$ might be counted as the costs of monopoly. Interest groups and politicians might invest resources into changing the regulations until the present discounted value of invested resources equals the present discounted value of the monopoly, taking risk into account as well. The rent-seeking theory thus suggests that the waste of monopoly might be much greater $(P C B A)$ than explained by the standard theory of monopoly. ${ }^{12}$ However, modern governmental agencies use bureaucracies to change, control and enforce regulation. ${ }^{13}$ To be more precise, let us therefore include bureaucracy in the general rent-seeking model.

Downs (1965) defines bureaucracy as a relatively large organization, which is unable to objectively measure its profitability. Niskanen (1968) developed a theory of similarly de-

11 For the dynamic rent-seeking theory see Buchanan (1980).

12 For negative consequences of rent-seeking on economic growth see Murphy and Shleifer and Vishny (1993).

13 Stigler (1976) suggests that even the process of electing politicians might be ruled by bureaucracy. 
fined bureaucracy. ${ }^{14}$ According to Niskanen (1968), bureaucracy might influence politicians' decision-making as a relatively strong interest group. Politicians provide taxation to fund bureaucracy and bureaucracy maximize the budget funded by taxation. In this model, Niskanen (1968) argues that since politicians' perception of efficiency of bureaucracy is limited, bureaucracy might raise budget so that it is above efficient provision of public goods.

Let us assume that politicians' perception of efficient provision of public goods is equal to:

$$
B=B(Q), B^{\prime}>0, B^{\prime \prime}<0
$$

Bureaucracy buys resources in competitive market, thus its cost function is similar to firm's cost function:

$$
C=C(Q), C^{\prime}>0, C^{\prime \prime}>0
$$

Since politicians' perceptions of efficiency of bureaucracy are limited, only bureaucracy knows its cost function. Politicians perceive only total output or total costs of bureaucracy. This makes bureaucracy a relatively strong interest group.

14 Chicago Public Choice (i.e. McChesney, 1987) does not assume bureaucracy as an independent interest group, but rather an organization of value maximizing agents. This assumption, however, misses principal difference between a bureaucratic management and a management of private organizations.

Downs (1965) characterizes a bureaucratic management as follows. "An organization is a bureau if and only if it possesses the following four primary characteristics:

1. It is large; that is, the highest ranking members know less than half of all the members personally.

2. A majority of its members are full-time workers who depend upon their employment in the organization for most of their income.

3. The initial hiring of personnel, their promotion within the organization, and their retention therein are at least theoretically based upon some type of assessment of the way in which they have performed or can be expected to perform their organizational roles rather than upon either ascribed characteristics (such as religion, race, or social class) or periodic election by some outside constituency.

4. The major portion of its output is not directly or indirectly evaluated in any markets external to the organization by means of voluntary quid pro quo transactions." (Downs, 1965, p.p. 439 - 440)

Niskanen (1968) characterizes bureaucracy as follows: "The model outlined in this section [bureaucracy model] is based on the following two critical characteristics of bureaus: (1) Bureaucrats maximize the total budget of their bureau, given demand and cost conditions, subject to the constraint that the budget must be equal to or greater than the minimum total costs at the equilibrium output. (2) Bureaus exchange a specific output (or combination of outputs) for a specific budget. For this paper, thus, bureaus are defined by these two characteristics. "(Niskanen, 1968, p. 293)

Crucial implication of both characteristics of bureaucracy is according to Niskanen (1968) following: "A careful analysis would indicate that the same output could be achieved at a lower budget, but the analyst should expect no cooperation from the bureau since it has no incentive to either know or reveal its minimum cost function." (Niskanen, 1968, p. 296)

This implication suggests that a bureaucratic management faces different incentives in comparison with private firms. Predecessor of this approach was Mises (2002) who argues that bureaucracy is principally inefficient. 
Let us assume that bureaucracy does not turn funds back to the politicians. In this case equality might be set up as bureaucracy's objective function.

$$
\mathrm{O}_{B}=\mathrm{B}(\mathrm{Q})+\lambda(\mathrm{B}(\mathrm{Q})-\mathrm{C}(\mathrm{Q}))
$$

Let us derive first-order conditions

$$
\begin{aligned}
& B^{\prime}(Q)=\frac{\lambda}{1+\lambda} C^{\prime}(Q) \\
& B(Q)=C(Q)
\end{aligned}
$$

Nevertheless, efficient provision of public goods suggests that marginal public benefits of extra unit of bureaucracy's output are equal to marginal costs.

$$
B^{\prime}(Q)=C^{\prime}(Q)
$$

In equation (4), the Lagrangian multiplier represents the marginal utility of an extension of the bureaucracy's budget constraint. Since the Lagrangian multiplier is a positive number, the equation (4) implies $B^{\prime}<C^{\prime}$. Then the marginal public benefits of extra unit of bureaucracy's output are lower than marginal costs and bureaucracy's provision of public goods. This condition derived from equation (4) does not correspond with the condition of efficient provision of public goods in equation (6). For this reason, the provision of public goods by bureaucracy is inefficient.

Figure 2: Bureaucratic inefficiency

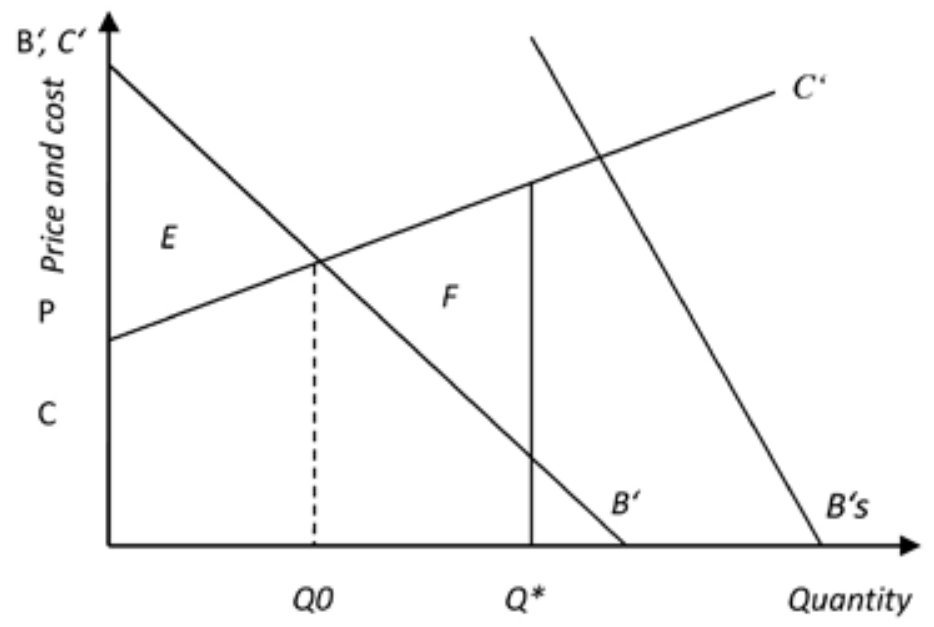

Source: Niskanen (1968)

Figure 2 shows a diagram of bureaucratic inefficiency. Niskanen (1968, p. 75) assumes that $B$ and $C$ are quadratic functions, thus $B^{\prime}$ and $C^{\prime}$ are linear functions. According to the politicians' perception of efficient provision of public goods, the bureaucracy is sup- 
posed to extract funds for provision of Q0. Nevertheless, since the politicians' perception of bureaucracy's costs $C^{\prime}$ is limited and bureaucracy is a relatively strong interest group, it might request funds for provision of $Q^{*}$ public goods. With the provision of $Q^{*}$ public goods, bureaucracy receives consumer surplus of triangle $E$, which is equal to triangle $F$. Bureaucracy thus might invest resources into requesting $\mathrm{F}$ until the present discounted value of invested resources equals the present discounted value of the bureaucracy, taking risk into account. Thus, if corruption induces politicians to rent-seeking and politicians use bureaucracy to change, control and enforce regulations, the waste of politicians' rentseeking is even greater.

Let us briefly summarize. According to the Virginia Public Choice analytical apparatus, benevolent despots might change regulations so that they protect pressure group's production against competition in exchange for bribes and thus waste resources on changing the regulations. Nevertheless, in reality, regulations are changed, controlled and enforced by inefficient bureaucracies. Therefore politicians' attempts to change the regulations in exchange for bribes are even more wasteful. This denies the Chicago Public Choice assumption of politicians behaving as homo economicus, because it suggests that when politicians are corrupt they are wasteful in order to cover their rent-seeking and bureaucratic rent-seeking costs by undesired taxation.

\section{A Rent-seeking Model with Corruption When Rent is Endogenous}

Previous arguments of the Virginia Public Choice proponents were based on the assumption that rent is exogenously given. In this section, let us introduce endogenous rent (Lambsdorff, 2002) into the general rent-seeking model (Mueller, 2009, chap. 15).

Let us assume that the probability that any interest group extracts the rent is assumed to be proportional to the interest groups' investment,

$$
\pi_{i}\left(I_{i}\right)=\frac{f_{i}\left(I_{i}\right)}{\sum_{j=1}^{n} f_{j}\left(I_{j}\right)}
$$

where $\partial \pi_{i} / \partial I_{i}>0$. Investment in rent-seeking might exhibit constant returns as $\partial^{2} \pi_{i} / \partial^{2} I=0$. Now, let us assume that investment in rent-seeking I with constant returns might be rewritten as $f_{i}\left(l_{i}\right)=I_{i}$.

Under the assumption that all rent-seekers are risk-neutral, each chooses a value of I that maximizes interest groups' expected gain $E(G)$.

$$
E(G)=\left(\frac{I}{I+T}\right) R-I
$$

where $T$ is the impact of the total investment of the other $n-1$ rent seekers, $T=\sum_{i \neq j} I_{j}$ and $\mathrm{R}$ is rent. Under the Cournot-Nash assumption that the other rent-seekers' investment remains fixed, the first order condition from equation (2) can be derived. 


$$
I=\frac{(n-1)}{n^{2}} R \frac{R}{I+T}-\frac{I R}{(I+T)^{2}}-1=0
$$

If we assume a symmetric equilibrium, from equation (2), we get

$$
I=\frac{(n-1)}{n^{2}} R
$$

Interpretation of the basic rent-seeking model (Mueller 2009, chap. 15) is the following. Risk-neutral interest groups invest I given in equation (4), as long as this I, when substituted into equation (2), yields non-negative expected gain. The basic rent-seeking model (Mueller 2009, chap. 15), however, assumes that rent $\mathrm{R}$ is given exogenously. Under the assumption of an endogenous rent (Lambsdorff, 2002), the basic rent-seeking model is more in compliance with our argumentation. Since real benevolent despots are not constrained by constitutions efficiently, they might impose taxes on private agents undesirably and thus create rents endogenously.

To explain this theoretically, let us assume that the size of the rent $\mathrm{R}$ is positively dependent on total rent-seeking investments $I=\sum_{i \neq j} I_{i}+\sum_{i \neq j} I_{j}$. Then $R=R(I)$, with $R^{\prime}>0$. This assumption also corresponds with our argument that in the world where bureaucracies provide public goods, the rule of law included, benevolent despots are furthermore incited to tax private agents undesirably to cover the bureaucratic inefficiencies. In our model, undesired tax presents a rent for the benevolent despots through which they also fund bureaucracies. Consequently, equation (2) might be rewritten.

$$
E(G)=\left(\frac{I}{I+T}\right) R(I+T)-I
$$

under the same assumptions, we can also rewrite the first order condition derived from equation $\left(2^{\prime}\right)$.

$$
\frac{R^{\prime} I}{I+T}+\frac{R}{I+T}-\frac{I R}{(I+T)^{2}}-1=0
$$

Assuming a symmetric equilibrium, from equation (2'), we get

$$
I=\frac{(n-1)}{n\left(n-R^{\prime}\right)} R
$$

Interpretation of equation ( $4^{\prime}$ ) is that if $R$ is larger (smaller) than 1 and $I$ is larger (smaller) than $R$. an increase in the number of competitors $n$ will decrease (increase) the total expenses for rent-seeking. In other words, with the assumption that politicians behave as benevolent despots, this model proves that in the case of a low number of interest groups engaging in corruption and lobbying, rent-seeking competition through corruption and 
lobbying reduces overall economic efficiency. This implication theoretically corresponds with a situation, where the rent is provided to a low number of interest groups with strong negotiating power - typically bureaucracies. ${ }^{15}$

There are regional empirical studies supporting our argument with respect to corruption (i.e. Hanousek and Kočenda, 2011). Nevertheless, this kind of studies supports our argument rather through investigation of relations among variables than through illustration of endogenous emergence of corrupt organizations. To fill this gap in recent empirical research let us illustrate this implication using a specific example. In Central and Eastern Europe after the collapse of the communist regime, a lot of interest groups were able to compete for the creation of legislation. However, in this period of replacement of old politicians by new ones, old bureaucracies remained relatively unchanged. Early transition of Central and Eastern Europe thus might be referred to as a period of creation of new legislation within old bureaucratic practices. According to some literature, even though this period was a period of increased activity of interest groups which led to corruption and lobbying, efficient regulation was not set up. For instance, Johnson et al (2000) argue that the so-called "tunnelling" was the result of weak political institutions, especially their inability to set and enforce an efficient legislative framework. Cull, Matesová and Shirley (2002) argue that inefficient law enforcement and inefficient regulations resulted in the problems of looting or asset-stripping.

Corrupt practices like theft, "tunnelling" and asset striping provided evidence that old bureaucracies participated on rents provided by earlier communist politicians. Communist politicians respected bureaucratic' claims on rents (Levy, 1990, Shleifer and Vishny, 1992, Anderson and Boettke, 1997) As a result, later, when communist politicians were replaced, privatization of the state ownership officially targeted to general public led to the legalization of communist bureaucratic claims for rents in most cases. Bureaucrats were a strong interest group in the privatization process, therefore "tunnelling" and asset striping together with other corrupt practices prevailed over the establishment of efficient legislation and regulation, i. e. efficient rule of law.

\section{Selected Anecdotic Evidence of Bureaucratic Corruption in the Czech and Slovak Republics}

To support our theoretical arguments empirically, let us present selected unique anecdotic evidence of bureaucratic corruption from the early period of transition in the Czech and Slovak Republics. The reason for choice of relatively "old" historical examples was that this period in the history of the Czech and Slovak Republics is revolutionary with respect to construction of legal system. Even though the legal system in the Czech and Slovak Republics is changing such deep change was not repeated yet. The source of the presented evidence is mostly the Czech and Slovak newspapers which reported on political corruption. We believe that despite of newspapers' commercial bias, some publicly presented

15 In Virginia Public Choice framework the higher number of competitors for privileges lowers inefficiency of the system. 
cases of bureaucratic corruption in the transition period of the Czech and Slovak Republics can provide clear and realistic illumination of the modelled political process.

The even more negative perception of corruption in the Czech Republic was greatly affected by the scandal of Jaroslav Lizner and Viktor Kožený. Jaroslav Lizner was convicted of abusing the authority of a public official in connection with the privatization of the Klatovy dairy (KD). A tender for a 34\% share in KD during the second wave of the voucher privatization was cancelled in July 1994 by Minister Karel Dyba, because of doubts about the negotiation process with the winning company Trans World International (TWI). A representative of TWI, Luboš Sotona passed on a suitcase planted by the police to Lizner on April 31 st 1994, containing 8,334,500 Czech crowns (Reed, 1996, p. 225). Jaroslav Lizner, as the former head of the centre for the voucher privatization, former head of the central registry of securities and the member of the securities commission, was the only highranking public official responsible for the voucher privatization, who was sentenced to 6 years in prison. ${ }^{16}$ In 2004 he requested the reopening of the case, however this request was denied.

The name of Viktor Kožený stirred emotions in most Czech citizens, which often led to the condemnation of the privatization process based on the role of corruption in it. Viktor Kožený, the founder of the Harvard Company and Consulting (HC\&C), became the owner of several important Czech companies after the first wave of the voucher privatization. During the year 1992, on eight occasions, he met with a former agent of the communist secret police and later with an employee of FBIS (the Federal security and information service), Václav Wallis. Reportedly, Kožený bought information from Wallis for about half a million crowns. In March 1994, Wallis was found guilty and sentenced to 37 months in prison. Subsequently, however, he was acquitted of any wrongdoing, because the alleged deal could not be proved. ${ }^{17}$

A subsequent anti-corruption program "clean hands", which was part of the anti-corruption initiative in 1998, was a specific answer of the Zeman government to the deteriorating perception of corruption linked to the privatization process in the Czech Republic. Based on this resolution, the government created an interdepartmental committee for the protection of economic interests. It was chaired by Stanislav Gross with a mandate to battle economic criminality and corruption. The committee was dissolved in the spring of 2000. According to a report by the European commission from the year 2000 (EC, 2000), the institutions created under this initiative prepared 209 cases to be prosecuted, only 70 of which were investigated by the police. 18 cases were cancelled, 10 were closed and only 6 made it to the court.

16 Lizner rejected the accusations, reasoning that "the costs associated with a privatization project are always a subject for discussion influenced by one's political views" (Reed, 1996, p. 224).

17 Václav Klaus declared: "I regard as completely absurd the idea that Mr. Kožený wanted to buy information of this type. The playing of this card is an ideological attack on the transformation of Czech Republic and an evil ideological attack on one of the foundations of the transformation process, that is, privatization." (Reed, 1996, p. 231) 
Another scandal involving a high ranking official in the Czech Republic was the "Srba" case. This case illustrates the connections of high ranking state officials and organized crime. Karel Srba allegedly traded without a mandate with the privileges for construction and reconstruction of governmental buildings, both at home and abroad. For example, according to the investigators, the company that was reconstructing the embassy in Zagreb (Block), paid Srba a five million crown bribe. "This amount was found in the car of Srba upon his arrest. The ex-secretary of the Ministry of Foreign Affairs of the Czech Republic defended himself, claiming that Jiři Sitár from Block only left the money for safekeeping" (Hospodářské noviny, 26th June, 2003). Srba was sentenced to eight years in prison not for corruption but for an attempt to murder a journalist Sabina Slonková. She presented a series of articles about the reconstruction of the Czech House in Moscow, managed by Srba, with unnecessary expenses for the state. Later, other corruption cases involving Srba emerged. However, none of the cases of corruption were proved, therefore he was cleared of all corruption charges. Jan Kavan, the head of the Ministry of Foreign Affairs, resigned because he appointed Srba in 1998 to paradoxically guarantee the "clean hands" program of the Zeman government.

In Slovakia, the privatization process after 1993 was even more under political control. After the division of the Czech and Slovak Federative Republic, the Slovak government abandoned the route of voucher privatization and embarked on the road of direct sales. The higher discretionary decision power and more space for corruption was probably the ultimate motivation for the abandonment of the voucher privatization process managed by a system of automatic auctions (Tríska, 2002). Clearly, the Slovak political elite was exposed to pressure directly calling for unfair advantages, something considered nonstandard in a democracy by foreign observers. Thus, the Slovak privatization process illustrates not only the bureaucratic corruption mode of privatization, but also the behavior of politicians as benevolent despots.

According to the daily newspaper Hospodářské noviny (30th September, 2002), the HZDS (Movement for Democratic Slovakia) representatives originally without any considerable assets, must have obtained most of the wealth from bribes and non-transparent privatization, since it could not be afforded from their official salaries. However, this will be ever harder to prove, since the only way to find the origins of their fortune would be to get official declarations of personal assets of the people involved. However, there was no such law in effect in Slovakia between 1990 and 1998.

The OECD report from the year 1999 (OECD, 1998, p. 101) highlights the lack of transparency using the example of Slovnaft, the Slovak refinery, which was sold to an unknown company Colorin for 620 million Slovak crowns. The Fund of National Assets did not provide any specific information to the shareholders of the company during a general shareholder meeting shortly before the privatization.

At this point it is important to mention Ján Ducký. He was an interesting person, who later became publicly known. He was the former secretary of the Minister of Interior in the communist government and a minister in three Slovak governments, including the first transformational government. He allegedly lobbied for the Slovak entrepreneurs which he had known during the communist years who acquired wealth suspiciously eas- 
ily (Schutz, 1999). During the years when Jan Ducký was the Minister of Economy, another company, Nafta Gbely was controversially privatized. He publicly denied any connections, even though he directly supervised the privatization process. The lucrative business was purchased by a company called Druhá obchodná with anonymous owners residing in an abandoned house in Bratislava suburbs. Nafta, originally being on a list of strategic companies not-to-be privatized at all, was sold for 500 million Slovak crowns, while its market capitalization was 3.2 billion Slovak crowns (Žitňanský, 2001). Later it turned out that Nafta Gbely belonged to the regional chairman of HZDS in Trnava and a former waiter Vladimír Poór. In 1996 Ducký was dismissed from the ministry for embezzling billions of crowns in revenues from the Slovak state treasury by issuing illegal export licenses to several businessmen.

Jan Ducký, the former secretary of a communist ministry, minister in three HZDS governments and the manager of the profitable Slovak Gas Company was found murdered in January 1999.

The most bizarre event demonstrating the political practices during the HZDS government was the abduction of Michal Kováč, the son of the Slovak president at that time. In 1995, he was transferred to Austria against his will. This operation was led by Ivan Lexa, the former head of the Slovak Intelligence Service (SIS) during the years 1994-1998. Lexa was accused of organizing the abduction and investigated, however after a direct order of the Prime Minister Mečiar he was subject to amnesty in 1998. According to The Economist (2002), it was Lexa who was responsible for the execution of dirty political tasks initiated by the prime minister.

In 1998 the investigations of Lexa were reopened by the order of the new Prime Minister Mikuláš Dzurinda. In March 1999, at that time the member of parliament, Lexa faced three charges: i) abuse of power as a state official, ii) abduction of a Slovak citizen abroad and iii) robbery. The Slovak National Council stripped Lexa of his immunity. This could have been done only after the mandate and immunity commissions of the Slovak National Council agreed with prosecution of Lexa for the abuse of power as a state official in November 1999 and Lexa spent a few months in prison.

In May 2000, despite the ban on leaving the country, even with a diplomatic passport, Lexa left Slovakia. "In fact, he was sunning himself at Umhlanga Rocks, a beach resort just north of Durban in South Africa, from a hotel owned by, guess who, his former secretary, who slipped the country around the same time as her boss, telling her mother she was off to Australia to learn English." (The Economist, 2002).

According to The Economist (2002), most of the fortune of Lexa and other accomplices of Mečiar was stolen from the state. In June 2006, after lack of sufficient evidence to convict Lexa, Vladimír Mečiar supported his rehabilitation in the Slovak National Council.

\section{Conclusions}

In this paper, we surveyed the theoretical discourse between the proponents of the Chicago Public Choice theory and the Virginia Public Choice school of thought on the 
relationship between corruption and economic efficiency. We explained that while the Chicago Public Choice theory admits that legal lobbying might improve the efficiency of the rule of law and consequently also the economic efficiency, the Virginia Public Choice theory maintains that corruption and lobbying induces politicians and bureaucrats to rent-seeking behavior and thus reduces the overall economic efficiency. We argued that the Virginia Public Choice theory argument is more realistic because it does not ignore the effect of bureaucratic rent-seeking.

We explained the rent-seeking theory and bureaucracy theory using a theoretical model to present how corruption reduces efficiency. Our model suggests that in the world where public goods including the rule of law are provided by bureaucrats, their provision must be inefficient and thus funded from undesired taxation imposed by politicians behaving as benevolent despots. To illustrate our argumentation, we have proposed an advanced rent-seeking model with endogenous rent, implying that even though there is a low number of interest groups including bureaucrats competing for rents, economic efficiency is reduced. To support this conclusion empirically, we have added a short literature survey of experiences with the establishment of the rule of law in the early stage of transition in Central and Eastern Europe. We have chosen this example as experimental evidence allowing relatively free legal and illegal competition among interest groups. Our quasi-experimental anecdotic evidence illuminates the reality of privatization process in the Czech and Slovak Republic. It shows that the reality of relatively intensive competition among interest groups was closely connected with bureaucratic rent-seeking, which is principally inefficient.

\section{Acknowledgements}

This article is the result of a research project supported by the Ministry of Education, Youth and Sports of the Czech Republic, no. VZ 6214648904 The Czech Economy in the Process of Integration and Globalization, and the Development of the Agricultural Sector and the Sector of Services under the New Conditions of the Integrated European Market", thematic area 01 "Macroeconomic and microeconomic performance of the Czech economy, and the Czech government's economic-political measures in the context of the integrated European market".

For inspiration we thank Professor Josef Šíma from CEVRO Institute, and Professor Jiří Schwarz from the University of Economics, Prague. Earlier discussion was published as a chapter in Human Capital and Investment in Education: The Collection of The XIV International Scientific Conference, Prague: University of Finance and Administration, 2011. For valuable comments we thank Associate Professor Radim Valenčík and Petr Wawrosz from University of Finance and Administration and all participants of the conference. 


\section{References}

ARCHIVES IHNED.CZ (2006). Praha: Economia.

ANDERSON, M. G., BOETTKE, P. (1997). Soviet venality: A rent-seeking model of the communist state. Public Choice. Vol. 93(1-2): pp. 37-53.

BANFIELD, E. C. (1975). Corruption as a Feature of Governmental Organization. Journal of Law and Economics. Vol. 18(3): pp. 587-605.

BECKER, G. S. (1983). A Theory of Competition Among Pressure Groups for Political Influence. Quarterly Journal of Economics. Vol. 98(3): pp. 371-400.

BRENNAN, G., BUCHANAN J. (1977). Towards a Tax Constitution for Leviathan. Journal of Public Economics. Vol. 8(3): pp. 255-273.

BRENNAN, G., BUCHANAN J. (1981). The Normative Purpose of Economic "Science": Rediscovery of an Eighteenth-Century Method. International Review of Law and Economics. Vol. 1(2): pp. 155-166.

BUCHANAN, J. M. (1980). Rent Seeking and Profit Seeking. In: Buchanan, Tollison and Tullock (ed.): Toward a Theory of the Rent-Seeking Society. Texas A\&M University Press, College Station: pp. 3-15.

BUCHANAN J., TOLLISON, R.D. (1999). The Theory of Public Choice II. The University of Michigan.

BUCHANAN J., TULLOCK G. (1967). Calculus of Consent: Logical Foundations of Constitutional Democracy. University of Michigan Press.

COLOMBATTO, E. (2003). Why Is Corruption Tolerated? Review of Austrian Economics. Vol. 16(4): pp. 367-379.

CULL, R., MATESOVÁ, J., SHIRLEY, M. (2002). Ownership and the Temptation to Loot: Evidence from Privatized Firms in the Czech Republic. Journal of Comparative Economics. Vol. 30(1): pp. 1-24.

DOWNS, A. (1965). A Theory of Bureaucracy. American Economic Review. Vol. 55(1/2): pp. 439-446.

EC (2000). Accession Report on the Czech Republic, European Commission, Brussels.

ECONOMIST (2002). The secret service gets its (own) man. 1st August, 2002.

JOHNSON, S., LA PORTA, R., LOPEZ-DE-SILANES, F., SHLEIFER, A. (2000). Tunneling. American Economic Review. Vol. 90(2): pp. 22-27.

HANOUSEK J., KOČENDA E. (2011). Vazba korupce a hospodářské svobody na veřejné finance a investice nových členů EU. Politická ekonomie. Vol. 59(3): pp. 310-328.

KRUEGER, A.O. (1974). The Political Economy of the Rent-Seeking Society. American Economic Review. Vol. 64(3): pp. 291-303.

LAMBSDORFF, J. G. (2002). Corruption and Rent-Seeking. Public Choice. Vol. 113(1-2): pp. 97-125.

LEVY, M.D. (1990). The bias in centrally planned prices. Public Choice. Vol. 67(3): pp. 213226.

MCCHESNEY, F.S. (1987). Rent Extraction and Rent Creation in the Economic Theory of Regulation. Journal of Legal Studies. Vol. 16(1): pp. 101-118

MCGUIRE, M. C., OLSON, M. (1996). The Economics of Autocracy and Majority Rule: The Invisible Hand and the Use of Force. Journal of Economic Literature. Vol. 34(1): pp. 72-96.

MISES, L.V. (2002). Byrokracie. Praha: Liberální institut.

MUELLER, D. C. (2009). Public Choice III. Cambridge (UK): Cambridge University Press.

MURPHY, K. M. AND SHLEIFER, A. AND VISHNY, R. W. (1993). Why Is Rent-Seeking So Costly to Growth? American Economic Review. Vol. 83(2): pp. 409 -414. 
NISKANEN, W. A. (1968). The Peculiar Economics of Bureaucracy. American Economic Review. Vol. 58(2), Papers and Proceedings of the Eightieth Annual Meeting of the American Economic Association (May 1968): pp. 293-305.

NORTH, D. C., WALLIS, J. J., WEINGAST, B. R. (2009). Violence and Social Order: A Conceptual Framework for Interpreting Recorded Human History. Cambridge (UK): Cambridge University Press.

OECD ECONOMIC SURVEY SLOVAK REPUBLIC (1999). OECD Publishing, Volume $1999 / 8$.

OLSON, M. (1993). Dictatorship, Democracy, and Development. American Political Science Review. Vol. 87(3): pp. 567-576

OLSON, M. (1996). Distinguished Lecture on Economics in Government Big Bills Left on the Sidewalk: Why Some Nations are Rich, and Others Poor. Journal of Economic Perspectives. Vol. 10(2): pp. 3-24.

OLSON, M. (1971). The Logic of Collective Action: Public Goods and The Theory of Groups. London (UK): Harvard University Press.

OTÁHAL, T. (2006a) Ekonomická analýza definice korupce. Národohospodářský obzor. Vol. 4(1): pp. 50-60.

OTÁHAL, T. (2006b). Vývoj korupce v ČR v období transformace. CVKS Working paper 14/2006. Brno: Centrum výzkumu konkurenční schopnosti české ekonomiky.

OTÁHAL, T. (2007a). Vývoj korupce v SR v období transformace. CVKS Working paper 8/2007. Brno: Centrum výzkumu konkurenční schopnosti české ekonomiky.

OTÁHAL, T. (2007b). Why is Corruption a Problem of the State? Prague Economic Papers. Vol. 16(2): pp. 165-179.

PELTZMAN, S. (1976). Toward a More General Theory of Regulation. Journal of Law and Economics. Vol. 19(2): pp. 211-240.

POSNER, R. A. (1974). Theories of Economic Regulation. Bell Journal of Economics and Management Science. Vol. 5(2): pp. 335-358.

REED, Q. (1996). Political Corruption, Privatization and Control in the Czech Republic: A Case Study of Problems in Multiple Transition. Thesis submitted in partial fulfillment of the requirements for the degree of D. Phil in Politics. Faculty of Social Studies, University of Oxford.

ROTHBARD, M. N. (2001). Ekonomie státních zásahů [Man, Economy, and State]. Praha: Liberální institut.

SCHUTZ, P. (1999). Smrt významného lobbyisty. Týden. 18th January, 1999.

SCHWARZ, J. (2001). Deregulation vs. Re-regulation. Journal des Economistes et des Etudes Humaines. Vol. 11(4), Article 5.

SHLEIFER, A., VISHNY, R. W. (1992). Pervasive Shortages under Socialism. Rand Journal of Economics. Vol. 23(2): pp. 237-246.

SHLEIFER, A., VISHNY, R. W. (1993). Corruption. Quarterly Journal of Economics. Vol. 108(3): pp. 599-617.

SMITH, A. (2001). Pojednání o podstatě a původu bohatství národů [An Inquiry into the Nature and Causes of the Wealth of Nations]. Praha: Liberální institut.

STIGLER, J. G. (1971). The Theory of Economic Regulation. Bell Journal of Economics and Management Science. Vol. 2(1): pp. 3-21.

STIGLER, J. (1976). Sizes of Legislatures. Journal of Legal Studies. Vol. 17(5): pp. 17-34.

TŘíSKA, D. (2002). Východiska, cíle a principy provedení kupónové privatizace. In Sborník textů Kupónové privatizace. Praha: CEP. 
TULLOCK, G. (1996). Corruption Theory and Practice. Contemporary Economic Policy. Vol. 14( 3): pp. 6-13.

TULLOCK, G. (1967). The Welfare Costs of Tariffs, Monopolies, and Theft. Western Economic Journal. Vol. 5(3): pp. 224-232.

VARIAN, H. L. (1995). Mikroekonomie: Moderní př́stup. Praha: Victoria publishing.

ŽITŇANSKÝ, R. (2001). Konec loupeže století. Respekt. 15th January, 2001.

\section{Contact address}

Ing. Ladislava Grochová, Ph.D.

Department of Economics, FBE MENDELU in Brno

(ladislava.grochova@mendelu.cz)

Ing. Tomáš Otáhal (corresponding)

Department of Economics, FBE MENDELU in Brno

(tomas.otahal@mendelu.cz) 